ISSN 2597- 6052

\title{
Faktor Risiko Kejadian Demam Berdarah Dengue (DBD) di Kabupaten Indramayu
}

\author{
The Risk Factors of Dengue Hemorrhagic Fever in Indramayu Regency \\ Hairil Akbar ${ }^{* 1}$, Eko Maulana Syaputra ${ }^{2}$ \\ ${ }^{1,2}$ Program Studi Kesehatan Masyarakat Universitas Wiralodra \\ Email Korespondensi : hairilakbar@unwir.ac.id
}

\begin{abstract}
Abstrak
Demam Berdarah Dengue (DBD) merupakan salah satu masalah kesehatan di negara berkembang dan global. Penyakit DBD dikenal juga dengan istilah Dengue Haemoragic Fever (DHF), merupakan penyakit infeksi akut menular kepada manusia melalui perantara gigitan nyamuk Aedes yang mengandung virus dengue. Tujuan penelitian untuk mengetahui faktor risiko kejadian demam berdarah dengue (DBD) di Kabupaten Indramayu. Jenis penelitian ini adalah penelitian observasional analitik dengan menggunakan rancang bangun case control study. Populasi pada penelitian ini seluruh penduduk yang tinggal di Kabupaten Indramayu. Sampel penelitian terdiri dari sampel kasus dan kontrol yang terdiri dari 34 kasus dan 68 kontrol sehingga total keseluruhan sampel sebanyak 102 sampel. Teknik pengambilan sampel dipilih secara simple random sampling. Analisis data menggunakan uji statistik simple logistic regression. Hasil penelitian yaitu praktek $3 \mathrm{M}$ di rumah ( $\mathrm{p}=0,020$, $\mathrm{OR}=2,778 ; 95 \% \mathrm{CI}: 1,174-6,574)$ dan kebiasaan mengantung pakaian ( $\mathrm{p}=0,015, \mathrm{OR}=3,470 ; 95 \% \mathrm{CI}: 1,271-9,472)$ merupakan faktor risiko kejadian demam berdarah dengue (DBD) di Kabupaten Indramayu. Perlunya masyarakat melakukan upaya pencegahan penyakit DBD seperti mempraktekkan 3M di rumah, serta berperilaku hidup bersih dan sehat.
\end{abstract}

Kata Kunci : Demam Berdarah dengue, Faktor Risiko

\begin{abstract}
Dengue Hemorrhagic Fever (DHF) is one of the health problems in developing countries. Dengue Hemorrhagic Fever (DHF) is an acute infectious disease transmitted to humans through the bite of the Aedes mosquito containing the dengue virus. The purpose of this study was to obtain the risk factors for dengue hemorrhagic fever (DHF) in Indramayu Regency. This study applied observational analytic study and a case-control study design. The population in this study was entire population living in Indramayu Regency. The study samples divided into case and control samples, consisting of 34 cases and 68 controls respectively and totaling 102 samples. Sampling was carried out using simple random sampling technique while data analysis was done using simple logistic regression statistical test. The results of the study were three kind of habitual practices (3M) ( $p$ $=0.020, O R=2.778 ; 95 \%$ CI: 1.174-6.574) and habits of hanging clothes $(p=0.015$, OR $=3.470 ; 95 \%$ CI: 1,271-9,472) was a risk factor of DHF in Indramayu Regency. Therefore, there is a need for the community in the region to take efforts in DHF prevention by practicing three kind habitual practices (3M) at home, as well as carrying out clean and healthy lifestyle.
\end{abstract}

Keywords : Dengue hemorrhagic fever, Risk factors 


\section{PENDAHULUAN}

Demam Berdarah Dengue (DBD) merupakan masalah kesehatan masyarakat yang muncul kebanyakan di daerah tropis dan subtropis di dunia Penyakit DBD termasuk penyakit akut yang disebabkan oleh infeksi virus yang dibawa oleh nyamuk Aedes aegypti dan Aedes albopictus betina yang umumnya menyerang pada manusia (1). Demam Berdarah Dengue (DBD) merupakan masalah kesehatan masyarakat yang muncul kebanyakan di daerah tropis dan subtropis di dunia Penyakit DBD termasuk penyakit akut yang disebabkan oleh infeksi virus yang dibawa oleh nyamuk Aedes aegypti dan Aedes albopictus betina yang umumnya menyerang pada manusia. Virus itu menyebabkan gangguan pada pembuluh darah kapiler dan sistem pembekuan darah, sehingga mengakibatkan perdarahanperdarahan. Manifestasi klinis dari infeksi virus dengue dapat berupa demam dengue dan DBD dengue (2).

DBD merupakan salah satu masalah kesehatan global dan di negara berkembang. Centers for Disease Control and Prevention (CDC) melaporkan sekitar 2,5 milyar orang atau $40 \%$ dari populasi dunia, hidup di daerah yang terdapat risiko penularan DBD. World Health Organization (WHO), memperkirakan 50 sampai 100 juta infeksi terjadi setiap tahun, termasuk 500.000 kasus DBD dan 22.000 kematian (3). Demam berdarah menjadi penyakit endemik di lebih dari 100 negara di Afrika, Amerika, Mediterania Timur, Asia Tenggara dan Pasifik Barat, Perancis, Kroasia dan beberapa negara lain di Eropa (4).

Organisasi Kesehatan Dunia (WHO) memperkirakan bahwa lebih dari 50 juta kasus demam berdarah terjadi setiap tahun dan hampir setengah dari populasi dunia tinggal di daerah endemik demam berdarah. Faktor risiko potensial (geografi, lingkungan, dan status sosial ekonomi) sangat penting karena dapat mempengaruhi kejadian DBD. Pemerintah harus mengambil tindakan yang tepat dalam pengendalian penyakit DBD (5). Data dari seluruh dunia menunjukkan Asia menempati urutan pertama dalam jumlah penderita demam berdarah setiap tahunnya. Sementara di Asia Tenggara mencapai 1,3 miliar atau 52\% dari 2,5 miliar orang di seluruh dunia berisiko demam berdarah. Diperkirakan terdapat 100 juta kasus demam dengue (DD) dan 500.000 kasus DBD yang memerlukan perawatan di rumah sakit, dengan $90 \%$ penderitanya adalah anak-anak yang berusia kurang dari 15 tahun dan jumlah kematian oleh penyakit DBD mencapai 5\% dengan perkiraan 25.000 kematian setiap tahunnya. Dan terhitung sejak tahun 1968 hingga tahun 2011, WHO mencatat negara Indonesia sebagai negara dengan kasus DBD tertinggi di Asia Tenggara (3).

Penyakit DBD di Indonesia masih merupakan salah satu masalah kesehatan masyarakat. Berdasarkan laporan Balai Penelitian dan Pengembangan Kementerian Kesehatan Republik Indonesia, tercatat kasus DBD di Indonesia pada tahun 2015 sebanyak 129.650 kasus, meningkat dari 99.499 kasus pada tahun 2014 (6). Trend penyakit DBD di Indonesia tergolong fluktuatif, namun memiliki kecenderungan untuk meningkat sehingga pada tahun 2015, angka IR penyakit DBD di Indonesia telah melampaui target Nasional $(\leq$ 49). Hal ini menunjukkan bahwa perlu adanya evaluasi program pengendalian DBD yang selama ini telah berjalan guna mencegah peningkatan kasus DBD pada tahun-tahun berikutnya (7).

Integrasi masyarakat dalam pengendalian demam berdarah memerlukan pengetahuan, sikap dan praktik yang nyata. Studi penelitian ini sesuai yang dilakukan di wilayah Karibia Kolombia, dimana terjadinya penyakit DBD disebabkan oleh kurangnya pengetahuan, pendidikan rendah, dan sikap dalam pengendalian penyakit DBD (8). Studi penelitian yang dilakukan di Guangzhou, China menunjukkan bahwa hal yang paling penting dalam menurunkan infeksi DBD adalah adanya kesadaran masyarakat terkait pencegahan penyakit DBD, meningkatkan pengetahuan, membuang sampah pada tempatnya, dan selalu membersihkan saluran air yang berada di sekitar tempat tinggal agar tidak tergenang, dan penggunaan anti nyamuk. Kegiatan ini dapat menurunkan risiko terjadinya penyakit DBD (9). Di Brasil epidemi DBD dikaitkan dengan kedekatan tempat tinggal dengan perairan yang tidak terurus, air yang tergenang di kaleng dan barang-barang bekas. Hal ini sama dengan daerah di Pakistan, kondisi buruk dari rumah, seperti bak penampungan air yang tidak ditutup merupakan faktor risiko yang sangat signifikan untuk perkembangbiakan nyamuk Aedes aegypti dan Aedes albopictus (10).

Berdasarkan data dari Kemenkes RI tahun 2016, menunjukkan bahwa angka kasus kejadian DBD paling tinggi terdapat pada Provinsi Jawa Barat yaitu sebanyak 36.631 kasus, kemudian disusul Provinsi Jawa Timur yaitu sebanyak 24.005 kasus, Provinsi DKI Jakarta yaitu sebanyak 20.423 kasus, Provinsi Bali sebanyak 20.329 kasus, dan terakhir pada Provinsi Kalimantan Timur yaitu sebanyak 10.712 kasus. Angka incidence rate DBD pada Provinsi Jawa Barat 77,31 per 100.000 penduduk, jumlah kasus yang meninggal sebanyak 270 orang, dan angka case fatality rate $0,74 \%$ pada tahun 2016 (7).

Data dari Dinas Kesehatan Kabupaten Indramayu tahun 2013 kasus kejadian DBD sebanyak 189 kasus, tahun 2014 mengalami peningkatan sebanyak 323 kasus, tahun 2015 sebanyak 525 kasus, tahun 2016 mengalami peningkatan sebanyak 901 kasus, tahun 2017 sebanyak 113 kasus dan pelaporan data tahun 2018 dari bulan januari sampai bulan april tahun 2018 kejadian DBD sebanyak 21 kasus. Hasil survei awal pada bulan januari tahun 2019 kasus DBD naik menjadi 13 kasus dan selama tiga tahun terakhir, daerah endemis DBD tercatat ada di lima wilayah kerja Puskesmas Margadadi, Patrol, Balongan, Jatibarang dan Kertasemaya (11). 
Beberapa hasil penelitian sebelumnya menunjukkan bahwa selalu terjadi peningkatan prevalensi kejadian DBD, baik masyarakat yang tinggal di daerah perkotaan maupun di daerah pedesaan. Dari data tersebut, peneliti tertarik melakukan penelitian untuk mengetahui faktor risiko kejadian demam berdarah dengue (DBD) di Kabupaten Indramayu. Tujuan dari penelitian ini adalah untuk mengetahui faktor risiko kejadian demam berdarah dengue (DBD) di Kabupaten Indramayu seperti tingkat pendidikan, praktek 3M di rumah, dan kebiasaan menggantung pakaian.

\section{METODE}

Penelitian ini adalah penelitian observasional analitik dengan menggunakan rancang bangun case control study yang merupakan suatu penelitian analitik yang menyangkut bagaimana faktor risiko dipelajari dengan menggunakan pendekatan retrospektif. Penelitian ini dilakukan di Kabupaten Indramayu Provinsi Jawa Barat mulai dari bulan April sampai dengan bulan Juni 2019. Populasi pada penelitian ini adalah seluruh penduduk yang tinggal di Kabupaten Indramayu yaitu 1.709.994 jiwa sedangkan sampel pada penelitian ini sebagian penduduk yang tinggal di Kabupaten Indramayu yaitu 34 kasus DBD dan 68 kontrol yang tidak terkena DBD sehingga total keseluruhan sampel sebanyak 102 sampel. Teknik pengambilan sampel yang digunakan yaitu Simple random sampling. Pengumpulan data menggunakan kuesioner dengan melakukan wawancara langsung dengan responden. Analisis data menggunakan uji statistik simple logistic regression. Penyajian data menggunakan tabel dan narasi.

\section{HASIL}

Analisis bivariabel untuk menganalisis dan mengetahui pengaruh antara faktor risiko yang berkontribusi terhadap kejadian demam berdarah dengue (DBD). Analisis bivariabel yang digunakan pada penelitian ini adalah regresi logistik sederhana (simple logistic regression).

\section{Tingkat Pendidikan}

Tingkat pendidikan responden dalam penelitian ini dibagi menjadi dua yaitu tingkat pendidikan rendah dan tingkat pendidikan tinggi. Distribusi kejadian demam berdarah dengue (DBD) berdasarkan tingkat pendidikan dapat dilihat pada berikut.

\section{Tabel 1}

\begin{tabular}{|c|c|c|c|c|c|c|}
\hline \multirow[t]{2}{*}{ Variabel } & & $\begin{array}{l}\text { ejadia } \\
\text { ardara }\end{array}$ & $\begin{array}{l}\text { Der } \\
\text { Der }\end{array}$ & & \multirow{3}{*}{$\begin{array}{c}\rho \\
\text { value }\end{array}$} & \multirow{3}{*}{$\begin{array}{c}\text { OR } \\
(95 \% \\
\text { CI })\end{array}$} \\
\hline & \multicolumn{2}{|c|}{ Kasus } & \multicolumn{2}{|c|}{ Kontrol } & & \\
\hline $\begin{array}{l}\text { Tingkat } \\
\text { Pendidikan }\end{array}$ & $\mathrm{n}$ & $\%$ & $\mathrm{n}$ & $\%$ & & \\
\hline Rendah & 25 & 73,5 & 43 & 63,2 & 0201 & 615 \\
\hline Tinggi & 9 & 26,5 & 25 & 36,8 & 0,501 & 015 \\
\hline
\end{tabular}

\begin{tabular}{llllll}
\hline Jumlah & 34 & 100 & 68 & 100 & $\begin{array}{c}(0,652- \\
4,002)\end{array}$ \\
\hline
\end{tabular}

Tabel 1, menunjukkan bahwa kelompok responden yang menderita demam berdarah dengue (DBD) (kasus) sebanyak 73,5\% pada kelompok responden yang berpendidikan rendah, sedangkan kelompok responden yang tidak menderita demam berdarah dengue (DBD) (kontrol) sebanyak 63,2\% pada kelompok responden yang berpendidikan rendah. Hal ini menunjukkan bahwa proporsi kelompok responden yang berpendidikan rendah cenderung lebih besar menderita demam berdarah dengue (DBD) dari pada kelompok responden yang tidak menderita demam berdarah dengue (DBD).

Hasil uji statistik didapatkan nilai $(\mathrm{p}=0,301$, $\mathrm{OR}=1,615 ; 95 \% \mathrm{CI}: 0,652-4,002$ ) berarti tidak terdapat pengaruh tingkat pendidikan terhadap kejadian demam berdarah dengue (DBD) sehingga bukan merupakan salah satu faktor risiko kejadian demam berdarah dengue (DBD) di Kabupaten Indramayu.

\section{Praktek 3M di Rumah}

Praktek 3M di rumah dalam penelitian ini dibagi menjadi dua yaitu buruk dan baik. Distribusi kejadian demam berdarah dengue (DBD) berdasarkan praktek 3M di rumah dapat dilihat pada berikut.

Tabel 2.

\begin{tabular}{|c|c|c|c|c|c|c|}
\hline \multirow[t]{2}{*}{ Variabel } & & $\begin{array}{l}\text { jadia } \\
\text { rdara }\end{array}$ & $\begin{array}{l}\text { Dem } \\
\text { Den }\end{array}$ & & \multirow{3}{*}{$\begin{array}{c}\rho \\
\text { value }\end{array}$} & \multirow{3}{*}{$\begin{array}{c}\text { OR } \\
(95 \% \\
\text { CI) }\end{array}$} \\
\hline & \multicolumn{2}{|c|}{ Kasus } & \multicolumn{2}{|c|}{ Kontrol } & & \\
\hline $\begin{array}{l}\text { Praktek 3M } \\
\text { di Rumah }\end{array}$ & $\mathrm{n}$ & $\%$ & $\mathrm{n}$ & $\%$ & & \\
\hline Buruk & 17 & 50,0 & 18 & 26,5 & & 2,778 \\
\hline Baik & 17 & 50,0 & 50 & 73,5 & 0,020 & $(1,174-$ \\
\hline Jumlah & 34 & 100 & 68 & 100 & & $6,574)$ \\
\hline
\end{tabular}

Berdasarkan Tabel 2, menunjukkan bahwa kelompok responden yang menderita demam berdarah dengue (DBD) (kasus) sebanyak 50,0\% pada kelompok responden yang praktek $3 \mathrm{M}$ di rumah buruk, sedangkan kelompok responden yang tidak menderita demam berdarah dengue (DBD) (kontrol) sebanyak 26,5\% pada kelompok responden yang praktek $3 \mathrm{M}$ di rumah buruk. Hal ini menunjukkan bahwa proporsi kelompok responden yang praktek $3 \mathrm{M}$ di rumah buruk cenderung lebih besar menderita demam berdarah dengue (DBD) dari pada kelompok responden yang tidak menderita demam berdarah dengue (DBD).

Hasil uji statistik didapatkan nilai $(\mathrm{p}=0,020$, $\mathrm{OR}=2,778 ; 95 \%$ CI:1,174-6,574) berarti terdapat pengaruh praktek $3 \mathrm{M}$ di rumah terhadap kejadian demam berdarah dengue (DBD) sehingga praktek $3 \mathrm{M}$ di rumah merupakan salah satu faktor risiko kejadian demam berdarah dengue (DBD) di Kabupaten Indramayu. Responden yang terkena demam berdarah dengue (DBD) berisiko 2,778 kali pada responden yang 
tidak mempraktekkan 3M di rumah (buruk) dari pada yang sering mempraktekkan $3 \mathrm{M}$ di rumah (baik).

\section{Kebiasaan Menggantung Pakaian}

Kebiasaan menggantung pakaian dalam penelitian ini dibagi menjadi dua yaitu ya dan tidak. Distribusi kejadian demam berdarah dengue (DBD) berdasarkan kebiasaan menggantung pakaian dapat dilihat pada berikut.

Tabel 3.

\begin{tabular}{|c|c|c|c|c|c|c|}
\hline \multirow{3}{*}{ Variabel } & \multicolumn{4}{|c|}{ Kejadian Demam } & \multirow{5}{*}{$\begin{array}{c}\rho \\
\text { value }\end{array}$} & \multirow{5}{*}{$\begin{array}{c}\text { OR } \\
(95 \% \\
\mathrm{CI})\end{array}$} \\
\hline & \multicolumn{4}{|c|}{ Berdarah Dengue } & & \\
\hline & \multicolumn{2}{|c|}{ Kasus } & \multicolumn{2}{|c|}{ Kontrol } & & \\
\hline Menggantung & \multirow[t]{2}{*}{$\mathrm{n}$} & \multirow[t]{2}{*}{$\%$} & \multirow[t]{2}{*}{$\mathrm{n}$} & \multirow[t]{2}{*}{$\%$} & & \\
\hline Pakaian & & & & & & \\
\hline $\mathrm{Ya}$ & 28 & 82,4 & 39 & 57,4 & & 3,470 \\
\hline Tidak & 6 & 17,6 & 29 & 42,6 & 0,015 & $(1,271-$ \\
\hline Jumlah & 34 & 100 & 68 & 100 & & $9,472)$ \\
\hline
\end{tabular}

Berdasarkan Tabel 3, menunjukkan bahwa kelompok responden yang menderita demam berdarah dengue (DBD) (kasus) sebanyak 82,4\% pada kelompok responden yang memiliki kebiasaan mengantung pakaian, sedangkan kelompok responden yang tidak menderita demam berdarah dengue (DBD) (kontrol) sebanyak $57,4 \%$ pada kelompok responden yang tidak memiliki kebiasaan mengantung pakaian. Hal ini menunjukkan bahwa proporsi kelompok responden yang memiliki kebiasaan mengantung pakaian cenderung lebih besar menderita demam berdarah dengue (DBD) dari pada kelompok responden yang tidak menderita demam berdarah dengue (DBD).

Hasil uji statistik didapatkan nilai $(\mathrm{p}=0,015$, $\mathrm{OR}=3,470 ; 95 \% \quad \mathrm{CI}: 1,271-9,472)$ berarti terdapat pengaruh kebiasaan menggantung pakaian terhadap kejadian demam berdarah dengue (DBD) sehingga kebiasaan menggantung pakaian merupakan salah satu faktor risiko kejadian demam berdarah dengue (DBD) di Kabupaten Indramayu. Responden yang terkena demam berdarah dengue (DBD) berisiko 3,470 kali pada responden yang memiliki kebiasaan menggantung pakaian dari pada yang tidak memiliki kebiasaan menggantung pakaian.

\section{PEMBAHASAN}

Penyakit demam berdarah dengue (DBD) adalah penyakit menular yang disebabkan oleh virus dengue yang termasuk pada genus Flavivirus dan ada empat serotipe virus dengue. Penularan terjadi melalui gigitan nyamuk Aedes aegypti (12). Manusia yang tertular penyakit DBD dikarenakan oleh gigitan nyamuk Aedes aegypti. Nyamuk Aedes aegypti dewasa berukuran lebih kecil jika dibandingkan dengan rata-rata nyamuk lain. Nyamuk ini mempunyai dasar hitam dengan bintikbintik putih pada bagian badan, kaki, dan sayapnya. Nyamuk Aedes aegypti jantan mengisap cairan tumbuhan atau sari bunga untuk keperluan hidupnya sedangkan yang betina mengisap darah (13).

Hasil dari uji statistik pada penelitian ini bahwa tidak terdapat pengaruh tingkat pendidikan terhadap kejadian demam berdarah dengue (DBD) sehingga tingkat pendidikan bukan merupakan salah satu faktor risiko kejadian demam berdarah dengue (DBD) di Kabupaten Indramayu. Penelitian ini sejalan dengan penelitian yang dilakukan oleh Novrita, dkk tahun 2017 menyatakan bahwa tidak ada hubungan antara pendidikan dengan kejadian DBD di Wilayah Kerja Puskesmas Celikah Kabupaten Ogan Komering Ilir (14). Hal yang sama juga ditemukan oleh penelitian Widodo di Kota Mataram tahun 2012 dan penelitian Tanjung di Wilayah Kerja Puskesmas Sentosa Baru Kecamatan Medan Perjuangan tahun 2016 (15)'(16). Penelitian ini tidak sejalan dengan penelitian Koyadun, dkk tahun 2012 yang menunjukkan bahwa ada hubungan antara pendidikan rendah dengan kejadian DBD (17). Perbedaan ini terjadi karena beberapa responden telah mendapatkan informasi mengenai penyakit demam berdarah dengue (DBD) dari kegiatan penyuluhan yang dilakukan oleh pihak Puskesmas dan Posyandu, sedangkan para pelajar atau siswa mendapatkan informasi terkait penyakit demam berdarah dengue melalui pihak sekolah atau usaha kesehatan sekolah (UKS).

Peningkatan jumlah kejadian DBD diduga kuat berhubungan dengan faktor perilaku masyarakat dalam melakukan tindakan pemberantasan sarang nyamuk (PSN) yang masih buruk. Kondisi ini diperburuk dengan fakta bahwa belum ada obat dan vaksin yang dinilai efektif untuk penyakit DBD, sehingga perilaku PSN dinilai penting dilakukan untuk mencegah penularan DBD (6).

Hasil dari uji statistik pada penelitian ini bahwa terdapat pengaruh praktek $3 \mathrm{M}$ di rumah terhadap kejadian demam berdarah dengue (DBD) sehingga praktek $3 \mathrm{M}$ di rumah merupakan salah satu faktor risiko kejadian demam berdarah dengue (DBD) di Kabupaten Indramayu. Responden yang terkena demam berdarah dengue (DBD) berisiko 2,778 kali pada responden yang tidak mempraktekkan $3 \mathrm{M}$ di rumah (buruk) dari pada yang sering mempraktekkan $3 \mathrm{M}$ di rumah (baik). Penelitian ini sejalan dengan penelitian Kartini tahun 2016 yang menyatakan bahwa praktek $3 \mathrm{M}$ berhubungan dengan kejadian demam berdarah dengue (DBD) di Kota Madiun (18). Hal ini juga sejalan dengan penelitian Rahmawati, dkk tahun 2018 di Wilayah Kerja Puskesmas Kayen Kabupaten Pati dan Tamza, dkk tahun 2013 di Wilayah Kelurahan Perumnas Way Halim Kota Bandar Lampung (19)(20). 
Perilaku PSN 3M Plus merupakan perilaku hidup sehat yang bertujuan untuk mengendalikan tempat perindukan sarang nyamuk dan upaya menghindari kontak dengan Aedes yang merupakan vektor DBD. Apabila perilaku ini dilakukan dengan baik, maka dapat memutus rantai penularan DBD sehingga hasil yang diharapkan adalah angka kejadian DBD dapat menurun. Praktik menguras TPA, menutup TPA dan mengubur barang bekas atau yang biasa dikenal dengan istilah $3 \mathrm{M}$ Plus merupakan upaya pemberantasan saran nyamuk (PSN) DBD yang dicanangkan oleh pemerintah. Sebagaimana yang telah ditunjukkan dalam beberapa penelitian, praktik $3 \mathrm{M}$ Plus merupakan faktor protektif terhadap kejadian DBD. Bila 3M dilaksanakan oleh seluruh masyarakat, maka populasi nyamuk Aedes aegypti dapat ditekan serendah-rendahnya, sehingga penularan DBD tidak terjadi lagi. Kemauan dan tingkat kedisiplinan untuk menguras TPA pada masyarakat memang perlu ditingkatkan, mengingat bahwa kebersihan air selain untuk kesehatan manusia juga untuk menciptakan kondisi bersih lingkungan. Dengan kebersihan lingkungan diharapkan dapat menekan terjadinya berbagai penyakit yang timbul akibat dari lingkungan yang tidak bersih.

Kebiasaan menggantung pakaian didalam rumah merupakan indikasi menjadikesenangan beristirahat nyamuk Aedes aegypti. Kegiatan PSN dan 3M ditambahkan dengan cara menghindari kebiasaan menggantung pakaian di dalam kamar merupakan kegiatan yang mesti dilakukan untuk mengendalikan populasi nyamuk Aedes aegypti, sehingga penularan penyakit DBD dapat dicegah dan dikurangi (21). Nyamuk Aedes aegypti biasanya hinggap atau istirahat dalam rumah khususnya ditempat yang gelap atau pakaian yang digantung (22).

Hasil dari uji statistik pada penelitian ini bahwa terdapat pengaruh kebiasaan menggantung pakaian terhadap kejadian demam berdarah dengue (DBD) sehingga kebiasaan menggantung pakaian merupakan salah satu faktor risiko kejadian demam berdarah dengue (DBD) di Kabupaten Indramayu. Responden yang terkena demam berdarah dengue (DBD) berisiko 3,470 kali pada responden yang memiliki kebiasaan menggantung pakaian dari pada yang tidak memiliki kebiasaan menggantung pakaian di dalam rumah. Penelitian ini sejalan dengan penelitian Ayun, dkk tahun 2017 yang menunjukkan bahwa sampel yang mempunyai kebiasaan menggantung pakaian dikamar mempunyai risiko 7,933 kali lebih besar menderita DBD daripada sampel yang tidak mempunyai kebiasaan menggantung pakaian dikamar (23). Penelitian ini juga sejalan dengan penelitian Wahyu Mahardika (2009), yang menyatakan ada hubungan antara kebiasaan menggantung pakaian dengan kejadian DBD di Wilayah Kerja Puskesmas Cepiring Kecamatan Cepiring Kabupaten Kendal. Pada kelompok yang mempunyai kebiasaan menggantung pakaian mempunyai risiko 4,896 kali lebih besar menderita DBD dibandingkan dengan kelompok yang tidak mempunyai kebiasaan menggantung pakaian (24).

Masih banyaknya masyarakat memiliki kebiasaan mengantung pakaian di rumahnya setelah digunakan, biasanya di gantung di belakang pintu kamar atau di pintu lemari pakaian bahkan didinding ruang didalam rumah misalnya didinding kamar, ruang keluarga dan terkadang di belakang pintu kamar mandi serta ada yang membiarkan pakaian berserakan diatas tempat tidur. Pakaian yang sering digantung merupakan tempat yang disukai oleh nyamuk untuk hinggap dan beristirahat. Untuk mencegah hal tersebut maka sebaiknya pakaian yang sudah dipakai diletakkan ditempat baju kotor yang tertutup dan pakaian yang belum dipakai dilipat dan dirapikan didalam lemari. Karena nyamuk Aedes aegypti senang hinggap pada pakaian yang bergantungan dalam kamar untuk beristirahat setelah menghisap darah manusia.

\section{KESIMPULAN}

Tidak terdapat hubungan yang bermakna antara tingkat pendidikan dengan kejadian demam berdarah dengue (DBD). Tingkat pendidikan juga bukan merupakan faktor risiko kejadian demam berdarah dengue (DBD) di Kabupaten Indramayu. Terdapat hubungan yang bermakna antara praktek $3 \mathrm{M}$ di rumah dengan kejadian demam berdarah dengue (DBD). Praktek 3M di rumah merupakan salah satu faktor risiko kejadian demam berdarah dengue (DBD) di Kabupaten Indramayu. Terdapat hubungan yang bermakna antara kebiasaan menggantung pakaian dengan kejadian demam berdarah dengue (DBD). Kebiasaan menggantung pakaian merupakan salah satu faktor risiko kejadian demam berdarah dengue (DBD) di Kabupaten Indramayu. Perlunya dilakukan upaya kongkrit oleh Dinas Kesehatan Kabupaten Indramayu dan jajarannya dalam melakukan upaya pencegahan dan deteksi sejak dini kejadian demam berdarah dengue (DBD) agar angka kesakitan dan kematian DBD menurun di Kabupaten Indramayu Provinsi Jawa Barat. Serta masyarakat harus menerapkan PHBS dalam lingkungan keluarga.

\section{UCAPAN TERIMA KASIH}

Ucapan terima kasih kepada yang memberikan bantuan dana dan dukungan yaitu 1).Direktorat Riset dan Pengabdian kepada Masyarakat, Ditjen Penguatan Riset dan Pengembangan Kementerian Riset, Teknologi, dan Pendidikan Tinggi, 2).Ketua Yayasan Universitas Wiralodra Indramayu, 3).Rektor Universitas Wiralodra, 4).Kepala Lembaga Pusat penelitian dan Pengabdian pada Masyarakat Universitas Wiralodra, 5).Kepala Pusat Penelitian Universitas Wiralodra, 6).Dekan Fakultas Kesehatan Masyarakat Universitas Wiralodra, 7).Seluruh Dosen Fakultas Kesehatan Masyarakat 
Universitas Wiralodra, 8).Dinas Kesehatan Kabupaten Indramayu, 9).Seluruh Kepala Puskesmas di Kabupaten Indramayu dan Jajarannya, serta 10).Seluruh Masyarakat di Kabupaten Indramayu.

\section{DAFTAR PUSTAKA}

1. Mahmood S, Hafeez S, Nabeel H, Zahra U, Nazeer H. Does Comorbidity Increase the Risk of Dengue Hemorrhagic Fever and Dengue Shock Syndrome? ISRN Trop Med. 2013;2013:1-5.

2. Achmadi Umar fahmi. Buletin Jendela Epidemiologi: Demam Berdarah Dengue. Jakarta: Pusat Data dan Surveilans Epidemiologi Kementrian Kesehatan RI; 2010.

3. WHO. Dengue and Severe Dengue. Geneva: WHO; 2012.

4. WHO. Dengue Haemorrhagic Fever, Diagnosis, Treatment, Prevention and Control. Second Edition. Geneva: WHO; 2014.

5. Cao Z, Liu T, Li X, Wang J, Lin H, Chen L, et al. Individual and interactive effects of socioecological factors on dengue fever at fine spatial scale: A geographical detector-based analysis. Int J Environ Res Public Health. 2017;14(7).

6. Kemenkes RI. Profil Kesehatan Indonesia. Jakarta: Kemenkes RI; 2015.

7. Kemenkes RI. Profil Kesehatan Indonesia. Jakarta: Kemenkes RI; 2017.

8. Diaz-Quijano FA, Martínez-Vega RA, Rodriguez-Morales AJ, Rojas-Calero RA, LunaGonzález ML, Díaz-Quijano RG. Association between the level of education and knowledge, attitudes and practices regarding dengue in the Caribbean region of Colombia. BMC Public Health. 2018;18(1):1-10.

9. Chen B, Yang J, Luo L, Yang Z, Liu Q. Who is vulnerable to dengue fever? A community survey of the 2014 outbreak in Guangzhou, China. Int J Environ Res Public Health. 2016;13(7).

10. Toan DTT, Hoat LN, Hu W, Wright P, Martens P. Risk factors associated with an outbreak of dengue fever/dengue haemorrhagic fever in Hanoi, Vietnam. Epidemiol Infect. 2015;143(8):1594-8.

11. Dinas Kesehatan Kabupaten Indramayu. Profil Kesehatan Kabupaten Indramayu. Indramayu: Dinas Kesehatan Kabupaten Indramayu; 2018.

12. Rowe S, Thevarajan I, Richards J, Gibney K, Simmons C. The Rise of Imported Dengue Infections in Victoria, Australia, 2010-2016. Trop Med Infect Dis. 2018;3(1):9.

13. Guzman MG, Vazquez S. The complexity of antibody-dependent enhancement of dengue virus infection. Viruses. 2010;2(12):2649-62.

14. Novrita B, Mutahar R, Purnamasari I. Analisis Faktor Risiko Kejadian Demam Berdarah Dengue Di Wilayah Kerja Puskesmas Celikah Kabupaten Ogan Komering Ilir. J Ilmu Kesehat Masy. 2017;2017(1):19-27.

15. Widodo N.P. aktor-Faktor Yang Berhubungan Dengan Kejadian Demam Berdarah Dengue (DBD) Di Kota Mataram Provinsi Nusa Tenggara Barat. Universitas Indonesia; 2012.

16. Tanjung L. Hubungan Faktor Fisik Lingkungan Rumah Dan Karakteristik Penderita Terhadap Kejadian Demam Berdarah Dengue (DBD) Di Wilayah Kerja Puskesmas Sentosa Baru Kecamatan Medan Perjuangan. Universitas Sumatera Utara; 2016.

17. Koyadun S, Butraporn P, Kittayapong P. Ecologic and sociodemographic risk determinants for dengue transmission in urban areas in Thailand. Interdiscip Perspect Infect Dis. 2012;2012.

18. Kartini Puri Ratna. Indeks Prediktif Kejadian Demam Berdarah Dengue di Sekolah Dasar Kota Madiun Tahun 2016. Universitas Airlangga; 2016.

19. Rahmawati Ulfah, Joko Tri N. Hubungan Antara Praktik 3M dan Faktor Lingkungan Fisik Rumah dengan Kejadian Demam Berdarah Dengue di Wilayah Kerja Puskesmas Kayen Kabupaten Pati. JKM e-Journal. 2018;6(6).

20. Tamza Riza Berdian. Hubungan Faktor Lingkungan dan Perilaku dengan Kejadian Demam Berdarah Dengue (DBD) di Wilayah Kelurahan Perumnas Way Halim Kota Bandar Lampung. JKM e-Journal. 2013;2(2).

21. Deswara Primadatu. Hubungan Kepadatan Nyamuk Aedes Aegypti di Dalam Rumah Dengan Angka Kesakitan Demam Berdarah Dengue (DBD) Pada Masyarakat di Kota Metro Provinsi Lampung. Universitas Indonesia; 2012.

22. Depkes RI. Perilaku dan Siklus Hidup Nyamuk Aedes Aegypti. Bul (News Leter). 2004;

23. Luluk Lidya Ayun dan Eram Tunggul. Hubungan Antara Faktor Lingkungan Fisik dan Perilaku Dengan Kejadian Demam Berdarah Dengue (DBD) di Wilayah Kerja Puskesmas Sekaran, Kecamatan Gunungpati, Kota Semarang Tahun 2015. Public Heal Perspect J. 2016;2(6411411059):97-104.

24. Mahardika Wahyu. Hubungan Antara Perilaku Kesehatan dengan Kejadian Demam Berdarah Dengue (DBD) di Wilayah Kerja Puskesmas Cepiring Kecamatan Cepiring Kabupaten Kendal. Universitas Negeri Semarang.; 2009. 